\title{
Phytoplankton Composition and Distribution in the Coastal Area of Bachok, Kelantan.
}

\author{
Aishah Salleh and Nur Diyana Ruslan* \\ ${ }^{1}$ Institute of Biological Sciences, University of Malaya, 50603 Kuala Lumpur, Malaysia. \\ *diryana82@yahoo.com (corresponding author) \\ Received on $20^{\text {th }}$ July 2009, accepted in revised form $22^{\text {nd }}$ Decemeber 2009.
}

\begin{abstract}
A study on the biodiversity of phytoplankton was carried out at Bachok, Kelantan from $14^{\text {th }}$ to $18^{\text {th }}$ June 2008. The objective of the study was to document the phytoplankton biodiversity of this scientifically little known area. Twenty genera and 54 species from two major divisions, Bacillariophyta (diatom) and Pyrrophyta (dinoflagellate) were recorded. Diatoms were richest and most diverse, with 51 species from 18 genera. The dominant diatoms were Chaetoceros constrictum, Rhizosolenia alata, Rhizosolenia bergonii and Rhizosolenia hebatata. Recorded salinities ranged from $14.44 \mathrm{ppt}$ to $33.6 \mathrm{ppt}$, and $\mathrm{pH}$ from 7.17 to 8.07.
\end{abstract}

ABSTRAK Kajian mengenai biodiversiti fitoplankton telah dijalankan di Bachok, Kelantan bermula dari 14 hingga 18 Jun 2008. Objektif kajian ini adalah untuk mendokumentasikan biodiversiti fitoplankton dalam kawasan yang kurang maklumat saintifiknya. Dua puluh genus dan 54 spesies dari dua divisi utama, Bacillariophyta (diatom) dan Pyrrophyta (dinoflagelat) telah direkodkan. Diatom paling banyak ditemui dengan taburan tertinggi dengan 51 spesies dari 18 genus. Dominan diatom adalah Chaetoceros constrictum, Rhizosolenia alata, Rhizosolenia bergonii dan Rhizosolenia hebatata. Kepekatan saliniti direkodkan dari 14.44ppt hingga 33.6ppt, dan pH dari 7.17 hingga 8.07 .

(Keywords: phytoplankton, biodiversity, Bachok, IOES)

\section{INTRODUCTION}

Marine phytoplankton research in Malaysia has been largely patchy over the years. Quantitative study of plankton in Malacca Straits was first conducted in 1933 by Sewell [1], followed by Wickstead [2], Pathansali, [3], Chua \& Chong [4] and Shamsudin et al. [5]. Marine phytoplankton research was also conducted in the west Malaysian waters by Salleh et $a l$. in Langkawi [6] and around the offshore islands of Pulau Jarak, Pulau Perak and Pulau Sembilan during the first Scientific Expedition to the Seas of Malaysia (SESMA)[7]. Phytoplankton research in South China Sea (Malaysian waters) has however received little attention except the works of Chua [8] and Shamsudin [9].

Diatoms were the most conspicuous and widespread microplankton of the coastal marine waters of Johor, Kelantan and Terengganu [10]. Communities of diatoms (class Bacillariophyceae) can be extremely diverse in marine waters.

The purpose of the present study was to document the phytoplankton biodiversity within the vicinity of the Institute of Ocean and Earth Sciences (IOES) marine station at Bachok, Kelantan. The marine station has been designated as University of Malaya's focal point for marine research in the South China Sea.

\section{MATERIAL AND METHODS}

A total of 12 sampling stations were established; these included the river mouth at Kuala Kemasin S1 $\left(6^{\circ} 7^{\prime} 48.41^{\prime \prime} \mathrm{N}, 102^{\circ} 22^{\prime} 14.09^{\prime \prime} \mathrm{E}\right)$, the beach at Kuala Kemasin - S2 (6 $\left.{ }^{\circ} 7^{\prime} 29.15^{\prime \prime N}, 102^{\circ} 22^{\prime} 36.42^{\prime \prime E}\right)$, Sg. Rekang - S3 (6 ${ }^{\circ} 0$ '20. 90 "N, $\left.102^{\circ} 25^{\prime} 39.87^{\prime \prime E}\right)$, Sg. Dua (I) - S4 (5॰59'52 . 23" N, $102^{\circ} 25^{\prime}$ '58.26"E), Sg. Dua (II) - S5 (5 ${ }^{\circ} 59^{\prime} 46.83$ "N, $102^{\circ} 26^{\prime} 0.63$ "E), Sg. Dua (III) - S6 (5 $\left.59^{\prime} 43.41^{\prime \prime N}, 102^{\circ} 26^{\prime} 4.73^{\prime \prime} \mathrm{E}\right)$,

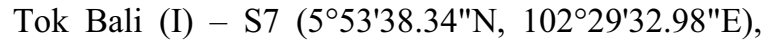

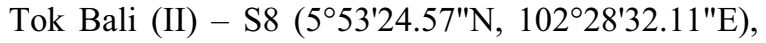

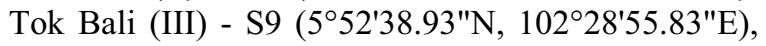
Sg. Semerak - S10 (5 51'42.26"N, 102 $\left.30^{\prime} 9.21^{\prime \prime} \mathrm{E}\right)$ and the river mouth of Sg. Semerak - S11 ( $\left.5^{\circ} 51^{\prime} 50.17 " \mathrm{~N}, 102^{\circ} 30^{\prime} 47.64^{\prime \prime E}\right)$. Figure 1 showed the locations of the 11 sampling stations.

Samples were collected using standard plankton net of $30 \mu \mathrm{m}$-mesh aperture. The samples were preserved in formalin (4\%) and subsequently prepared for species identification using light microscope. Light microscopy was performed using Olympus BX 51. The morphological structures of the specimens were then examined using the scanning electron 
microscopy (SEM). Several reference books and journals were used to identify most of the species $[10,11,12,13]$.

Water samples were collected using $500 \mathrm{ml}$ polythene bottles by dipping the bottle under the surface of the water. Chemical analyses of nitrate, phosphate and silica concentration were conducted in laboratory. Measurement of physical factors such as light intensity, water temperature, $\mathrm{pH}$, salinity, dissolved oxygen and water conductivity were recorded in-situ at the sampling sites.

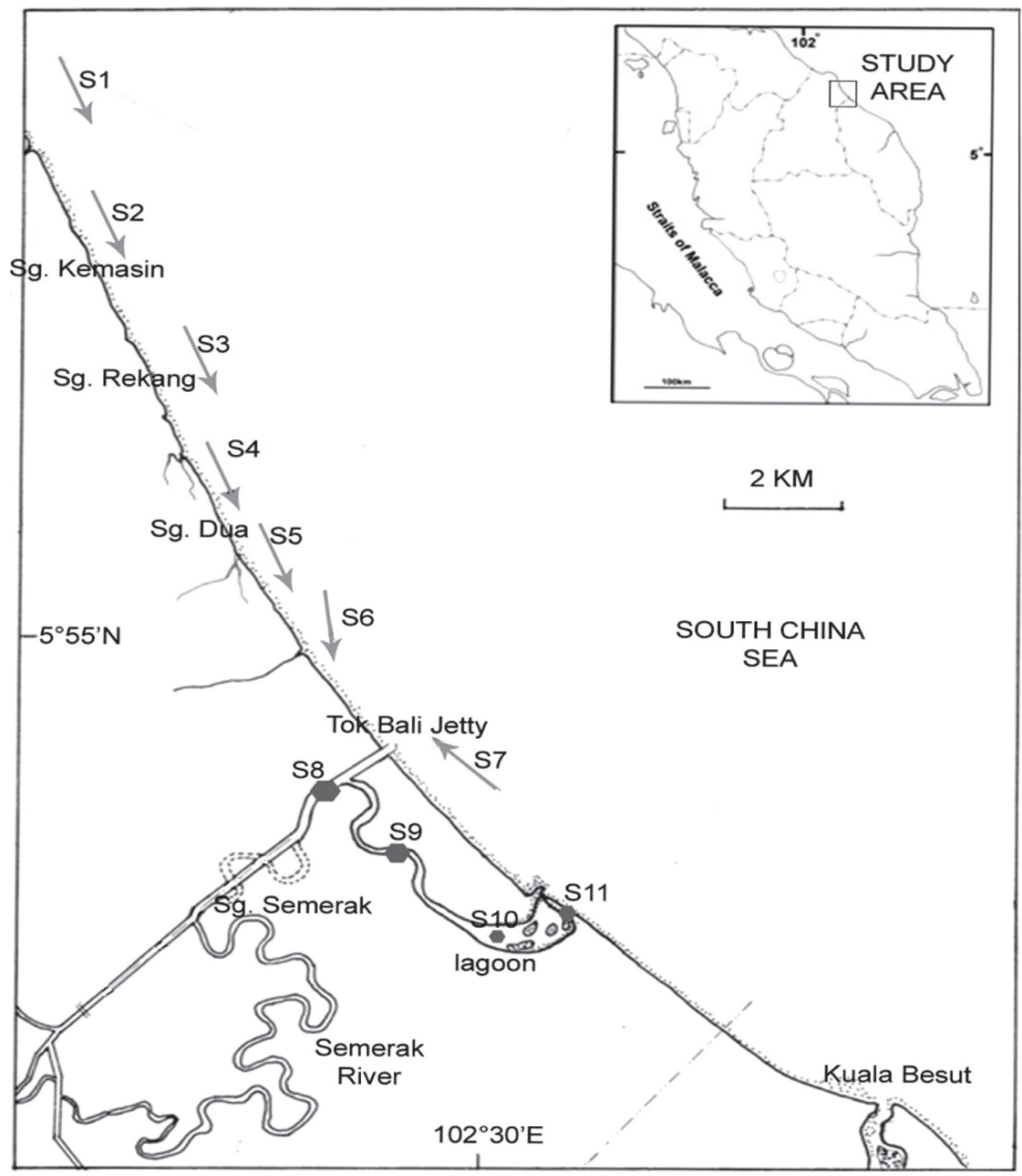

Figure 1. Location of the sampling sites. 


\section{RESULTS AND DISCUSSION}

The range of recorded salinities during the study was high; $33.60 \mathrm{ppt}$ at Tok Bali station and $14.46 \mathrm{ppt}$ at Sg. Semerak station.

A total of 54 species and 20 genera from two main divisions of phytoplankton were recorded (Table 1). The most abundant species were Bacillariophyta (diatoms) with 51 species, followed by Pyrrophyta (dinoflagellate) with three species. The diatoms that were recorded as abundant along the coastal area of Bachok were species belonging to the genera of Rhizosolenia, Chaetoceros, Thalassiothrix and Bacteriastrum. These species were also recorded as dominant in Malacca Straits [7].

Diatoms were abundant at the Kuala Kemasin estuary where Rhizosolenia spp. was the most abundant as blooms. The plankton blooms attributable to most species from the Bacillariophyta are not hazardous to humans [14].

Diatoms are good indicators of the environmental condition of rivers and streams because they respond directly and sensitively to the physical, chemical and biological changes of these ecosystems, particularly temperature and nutrient concentrations $[15,16,17]$. Compared to the other stations (S4, S5, S6, S7, S8, and S9), the most dominant diatoms recorded from $\mathrm{S} 1$ and S11 were Coscinodiscus, Ditylum, Biddulphia and some dinoflagellates (Pyrrophyta) including Ceratium and Protoperidinium. Shallow waters (S5, S6) recorded high abundance of Biddulphia spp. This genus was the most common in shallow waters near the coast [10].

The diversity and distribution of the phytoplankton are related to their physiological requirements such as dissolved oxygen, $\mathrm{pH}$, and nutrient content which can have a profound impact on the overall health or ecological state of the water. Eutrophication refers to the over-enrichment of the water by nutrients, particularly nitrogen and phosphorus, which increase phytoplankton growth. These nutrients are transported into the sea by rivers in solution or attached to sediments, thus increasing the nutrient loadings of coastal waters. Nitrate and phosphate are of special importance in that they often determine the productivity of water [18].

The nitrate concentrations (Table 2) at all stations were within 0.1 to $0.6 \mathrm{mg} / \mathrm{L}$, while phosphorus concentration ranged from 0.01 to $1.43 \mathrm{mg} / \mathrm{L}$. The highest silicate content occurred at station 10 with $0.39 \mathrm{mg} / \mathrm{L}$, whereas the lowest was at station 7
$(0.07 \mathrm{mg} / \mathrm{l})$. Silica is required by diatoms which were the dominant phytoplankton in the study sites [19, 20]. Silica may limit growth as well as the thickness of the cell wall [21].

Temperature, $\mathrm{pH}$ and dissolved oxygen are important factors used to verify either the oligotrophic or eutrophic status of water. Oligotrophic freshwater refers to very clean water with high drinking-water quality compared to the eutrophic condition which is due to excessive nutrients resulting in poor water quality. Eutrophication may cause harmful algal blooms as reported in Sabah [22] and Malacca Straits [23].

Dissolved oxygen in water can act as a pollution indicator [24, 25]. The present study shows a range of dissolved oxygen that ranged between 3.96 to 8.30 $\mathrm{mg} / \mathrm{L}$. It was found that high values of dissolved oxygen occurred at the surface where dissolved oxygen tends to equilibrate with atmospheric oxygen. The lowest dissolved oxygen concentration of 3.96 $\mathrm{mg} / \mathrm{L}$ was recorded at S11, while S6 showed the highest concentration of dissolved oxygen at 8.30 $\mathrm{mg} / \mathrm{L}$. The low nutrient ( $\mathrm{N}$ and $\mathrm{P}$ ) concentrations and high dissolved oxygen content indicate that the marine water across the coastal area of Bachok was generally oligotrophic.

\section{CONCLUSIONS}

Fifty-four species of phytoplankton were recorded from Bachok coastal waters. The phytoplankton at Bachok coastal waters were diverse but dominated by diatoms and dinoflagellates.

\section{ACKNOWLEDGEMENTS}

The authors are indebted to the Institute of Ocean and Earth Sciences (IOES) and University of Malaya, for support of this study. Grateful thanks are due to those who had assisted in the research especially the staff of the Institute of Biological Science for their technical support.

\section{REFERENCES}

1. Sewell, S. R. (1933). Marine copepod from Malay States. Buletin of the Raffles Museum, Singapore 8:25-31.

2. Wickstead, J. H. (1961). A quantitative study of some Indo-West Pacific Plankton. Colonial Office Fisheries Publication. 16, Her Majesty's Stationery Office, London. 
1b
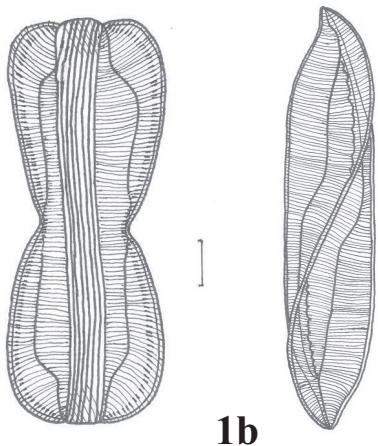

2

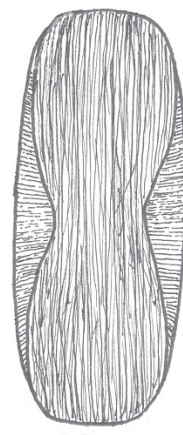

3

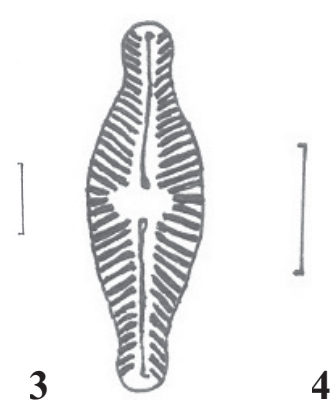

4
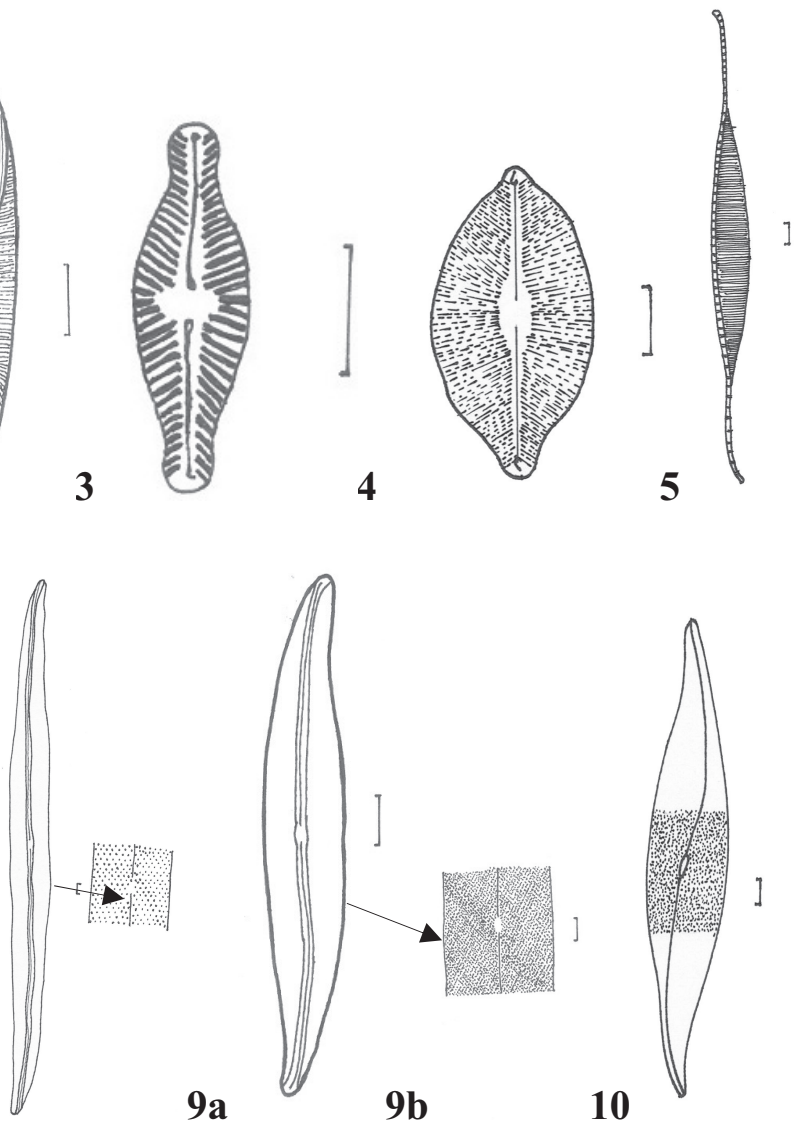

$9 a$

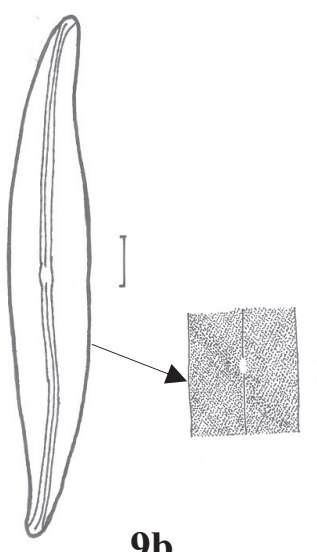

9b

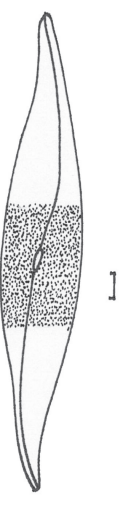

10

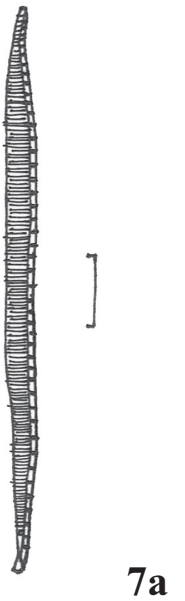

6

$7 a$

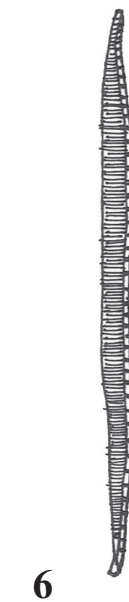

11

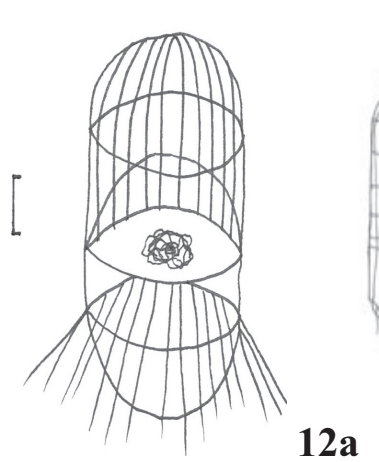

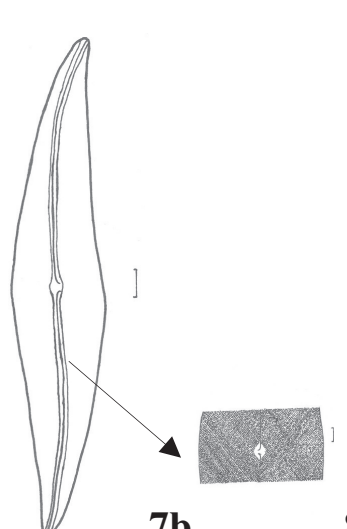

$7 b$

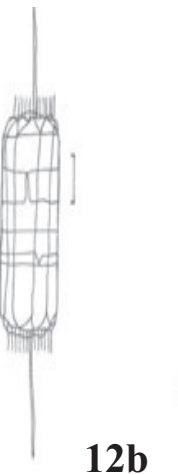

8

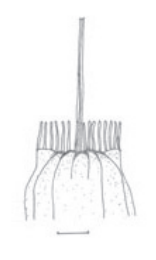

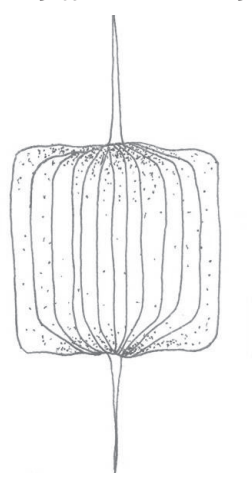

13b

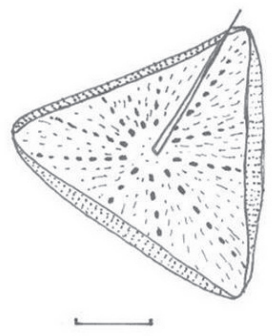

$13 a$

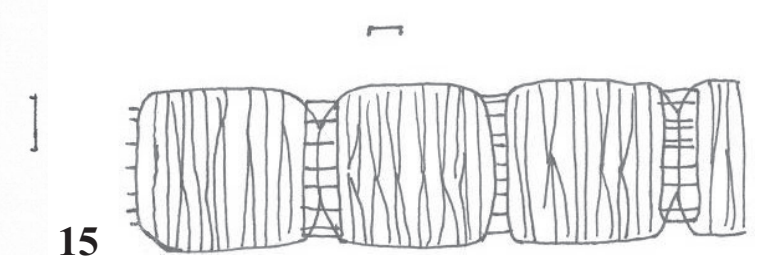

14

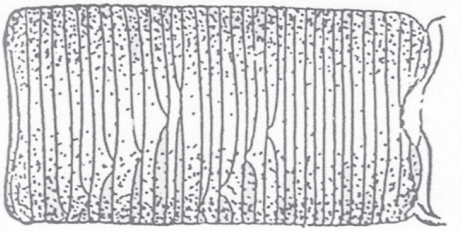

Plate 1. 1. Amphiprora alata; a valve view; b girdle view 2. Amphora quadrata 3. Navicula hustedii 4. Navicula pusilla 5. Nitzchia longissima 6. Nitzchia sigma 7a,b Pleurosigma angulatum 8 Pleurosigma elongatum 9a,b Pleurosigma salinarum 10. Pleurosigma pelagicum 11. Corethron pelagicum 12 Ditylum brightwellii; a, b girdle view 13. Ditylum sol 14. Guinardia flaccida 15. Lauderia annulata 
1
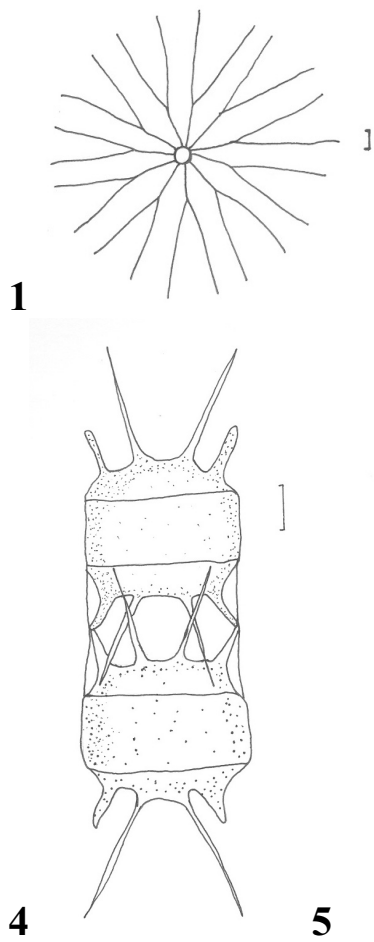

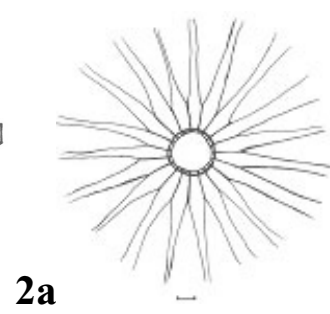

$2 \mathbf{a}$

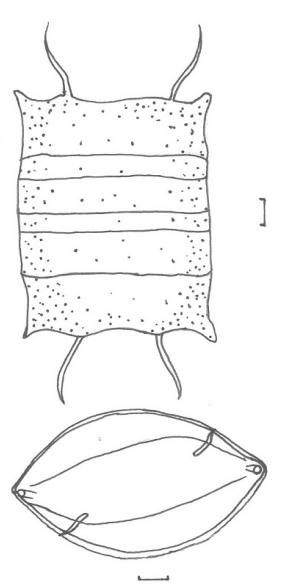

$\mathbf{2 b}$
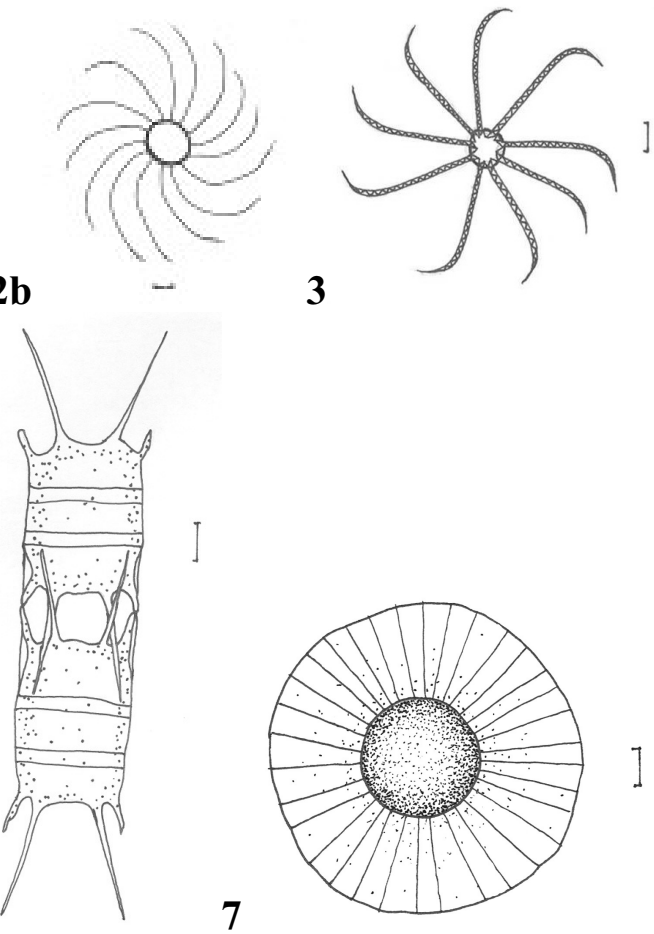

7

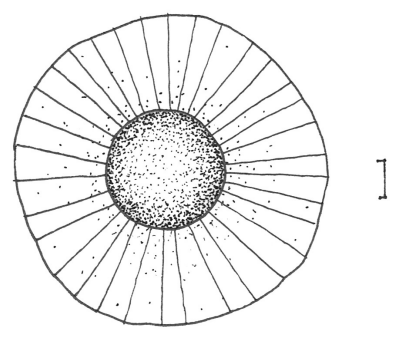

8

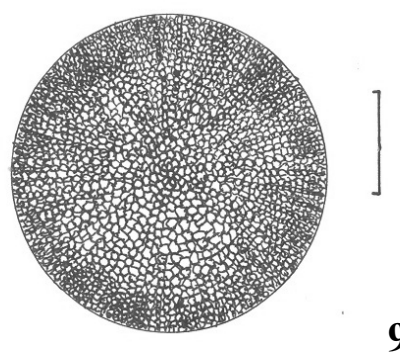

9

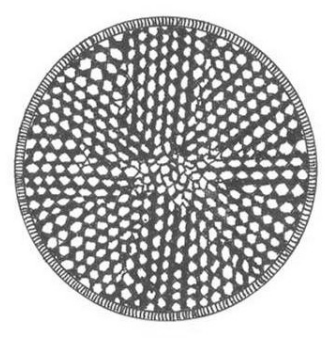

12

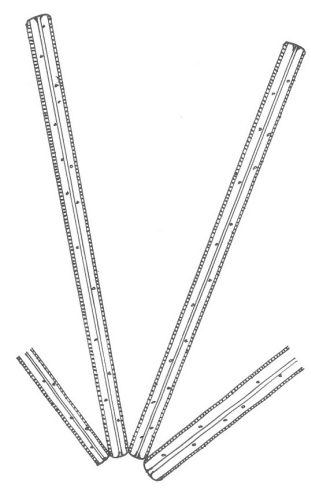

10

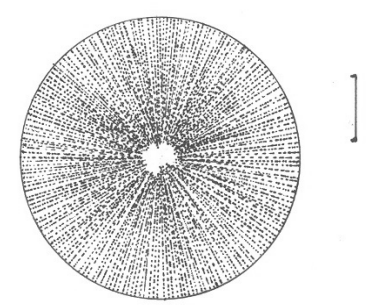

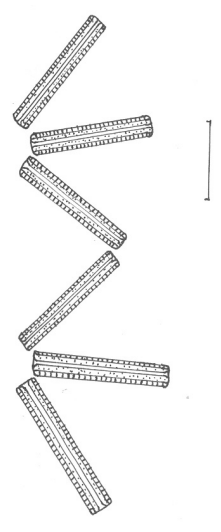

14

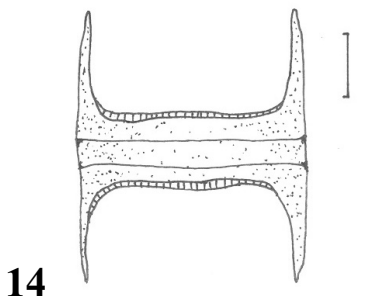

11

Plate 2. 1. Bacteriastrum delicatum 2. Bacteriastrum hyalinum 3. Bacteriastrum varians 4. Biddulphia mobiliensis; girdle view 5. Biddulphia regia 6. Biddulphia sinensis; girdle view 7. Planktoniella sol 8. Coscinodiscus asteromphalus 9. Coscinodiscus centralis 10. Coscinodiscus concinnus 11. Coscinodiscus radiatus 12. Thalassiothrix frauenfeldii 13. Thalassionema nitzschioides 14. Hemianulus sinensis 


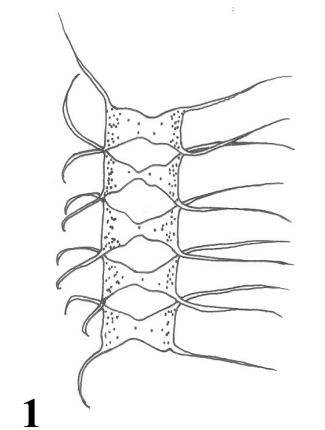

2
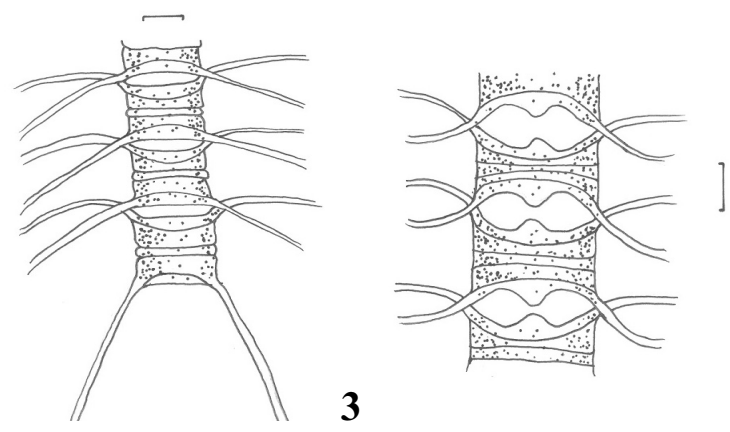

3

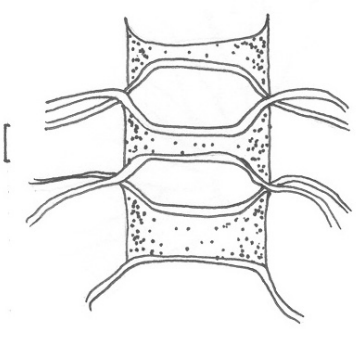

5

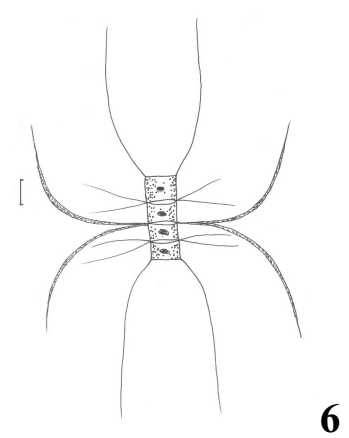

6

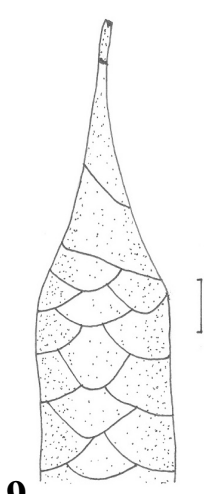

9

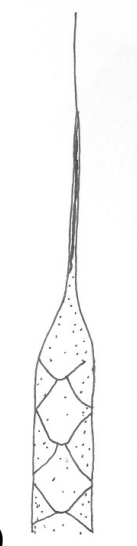

11

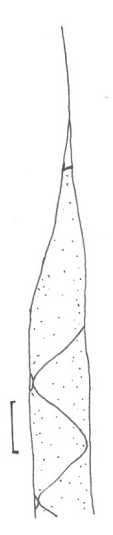

12
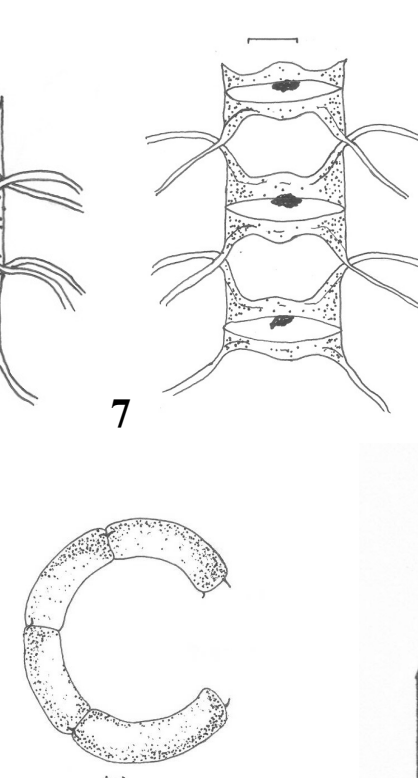

8
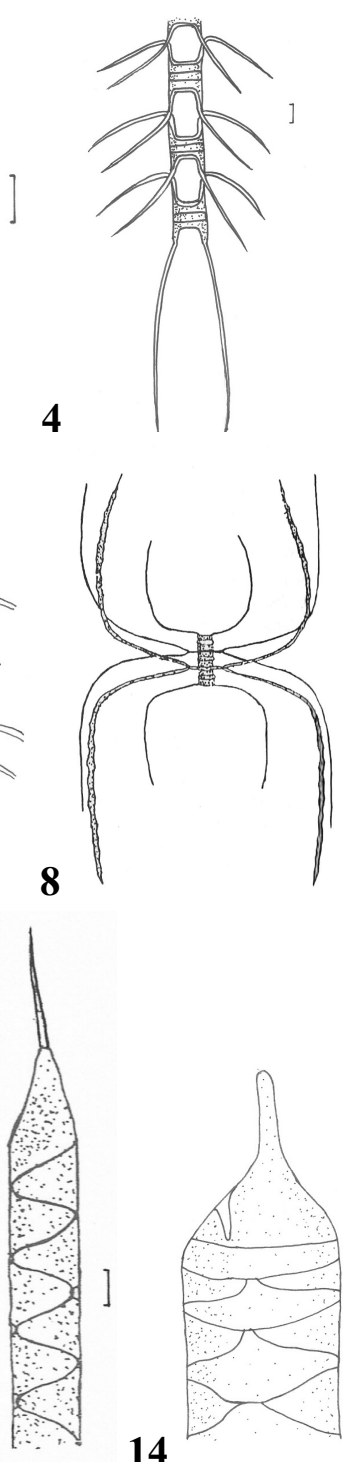

14

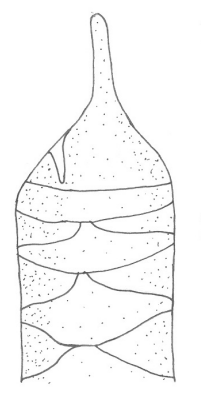

13

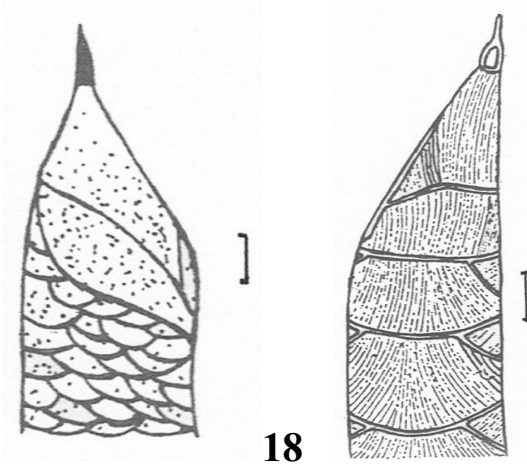

19

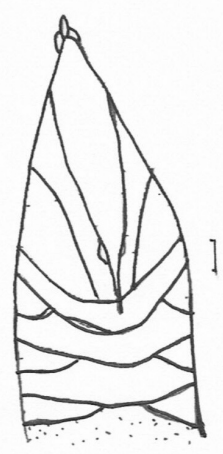

17

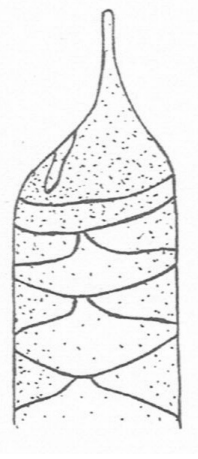

18

Plate 3. 1. Chaetoceros cursivetus 2. Chaetoceros constrictum 3. Chaetoceros didymum 4. Chaetoceros distans 5. Chaetoceros diversum 6. Chaetoceros decipiens 7. Chaetoceros lorenzianum 8. Chaetoceros leave 9. Rhizosolenia bergonii 10. Rhizosolenia setigera 11. Rhizosolenia hebetata 12 Rhizosolenia stolterforthii 13. Rhizosolenia calcar-avis 14. Rhizosolenia alata 15. Rhizosolenia alata var gracilima $\mathbf{1 6 .}$ Rhizosolenia alata var indica 17. Rhizosolenia acuminata 18. Rhizosolenia imbricata 19. Rhizosolenia styliformis 

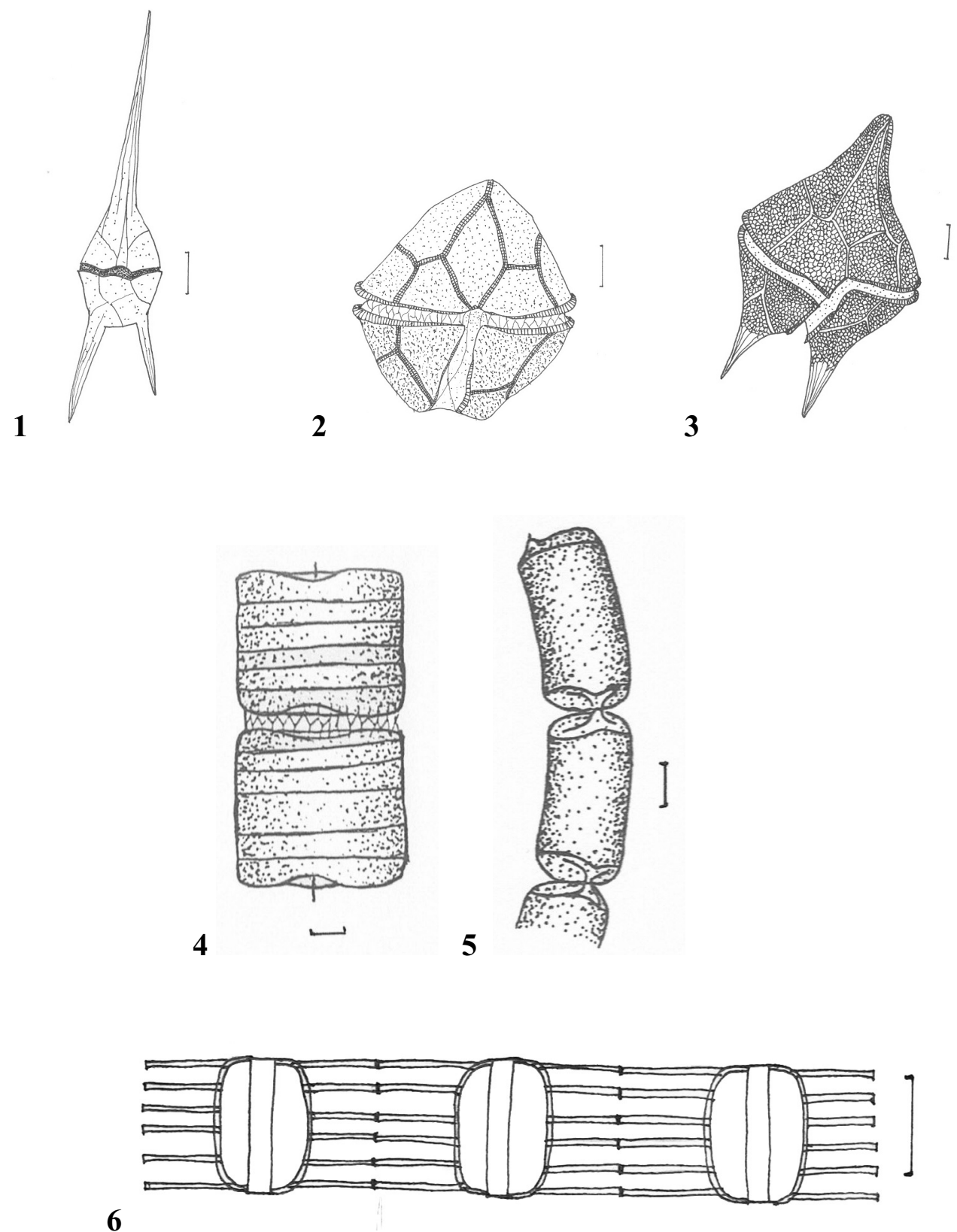

Plate 4. 1. Ceratium lineatum 2. Protoperidinium punctulatum 3. Protoperidinium oblongum 4. Schroderella schroderi 5. Cerataulina bergonii 6. Skletonema costatum. 
Table 1. List of phytoplankton species in Bachok, Kelantan (symbol '+' and '-' refer to present and absent respectively).

\begin{tabular}{llllllllllll}
\hline & \multicolumn{1}{c}{ Stations } \\
\cline { 2 - 8 } Species & S1 & S2 & S3 & S4 & S5 & S6 & S7 & S8 & S9 & S10 & S11 \\
\hline
\end{tabular}

\section{Bacillariophyta (Diatom)}

Amphiproraceae

1. Amphiprora alata Kutzing

Catenulaceae

\section{Amphora quadrata Breb}

Chaetocerotaceae

3. Bacteriastrum delicatulum Cleve

4. Bacteriastrum hyalinum Lauder

5. Bacteriastrum varians Lauder

6. Biddulphia mobiliensis (Bailey) Grunow

7. Biddulphia regia Ostenfeld

8. Biddulphia sinensis Greville

9. Chaetoceros curvisetus Mangin

10. Chaetoceros constrictum Gran

11. Chaetoceros didymium Ehr.

12. Chaetoceros distans Gran

13. Chaetoceros diversum Cleve

14. Chaetoceros decipiens Cleve

15. Chaetoceros leave Cleve

16. Chaetoceros lorenzianum Grunow

Corethraceae

17. Corethron pelagicum Castracane (Brun)

Coscinodiscaceae

18. Coscinodiscus asteromphalus $\mathrm{Ehr}$

19. Coscinodiscus centralis (Ehr.) A. Schmidt

20. Coscinodiscus concinnus W. Smith

21. Coscinodiscus radiatus Ehr.

Lithodesmiaceae

22. Ditylum brightwellii Grunow

23. Ditylum sol Grunow

Hemiauliceae

24. Hemiaulus sinensis Greville

25. Cerataulina bergonii H. Perag

Lauderiaceae

26. Lauderia annulata Cleve

Naviculaceae

27. Navicula hustedii Krasske

28. Navicula pusilla W. Sm 
Table 1. Continued

Stations

Species

$\begin{array}{lllllllllll}\text { S1 } & \text { S2 } & \text { S3 } & \text { S4 } & \text { S5 } & \text { S6 } & \text { S7 } & \text { S8 } & \text { S9 } & \text { S10 } & \text { S11 }\end{array}$

Bacillariaceae

29. Nitzchia longissima (Berb.) Ralf

30. Nitzchia sigma W. Sm

Thalassiosiraceae

31. Planktoniella sol (Wallic) Schutt

Pleurosigmataceae

32. Pleurosigma angulatum (Quek.) W. Sm.

33. Pleurosigma elongatum $\mathrm{W}$. Sm

34. Pleurosigma salinarum Grunow

35. Pleurosigma pelagicum Perag.

Rhizosoleniaceae

36. Rhizosolenia alata Brightwell

37. Rhizosolenia alata var gracilima

38. Rhizosolenia alata var indica

39. Rhizosolenia acuminata Gran.

40. Rhizosolenia bergonii Perag.

41. Rhizosolenia calcar-avis M. Schultze

42. Rhizosolenia setigera Brightwell

43. Rhizosolenia hebatata Bailey

44. Rhizosolenia imbricata Brightwell

45. Rhizosolenia stolterforthii Perag.

46. Rhizosolenia styliformis Brightwell

47. Guinardia flaccida (Castr.) Perag.

48. Schroderella schroderi (Bergon)

Skeletonemataceae

49. Skeletonema costatum Greville

Thalassionemataceae

50. Thalassiothrix frauenfeldii Grunow

51. Thalassionema nitzschioides Grunow

\section{Division : Pyrrophyta (Dinoflagellate)}

Ceratiaceae

52. Ceratium lineatum (Ehr) Cleve

Protoperidiniaceae

53. Protoperidinium punctulatum Paulsen (Balech)

54. Protoperidinium oblongum

References: S1 - River mouth of Kuala Kemasin; S2 - Beach at Kuala Kemasin; S3 - Sg. Rekang; S4 - Sg. Dua (I); S5 - Sg. Dua (II); S6 - Sg. Dua (III); S7 - Tok Bali (I); S8 - Tok Bali (II); S9 - Tok Bali (III); S10 - Sg. Semarak; S11- River mouth of Sg. Semerak. 
Table 2. Nutrient concentration and physical parameters analyzed from sampling locations at Bachok, Kelantan.

\begin{tabular}{ll}
\hline Parameters & Results (range) \\
\hline Nitrate $(\mathrm{mg} / \mathrm{L})$ & $0.1-0.6$ \\
Phosphate $(\mathrm{mg} / \mathrm{L})$ & $0.01-1.43$ \\
Silica $(\mathrm{mg} / \mathrm{L})$ & $0.07-0.39$ \\
Water temperature $\left({ }^{\circ} \mathrm{C}\right)$ & $30.84-32.22 \pm 0.5$ \\
pH & $7.17-8.07 \pm 0.05$ \\
DO $(\mathrm{mg} / \mathrm{L})$ & $3.92-8.30 \pm 0.05$ \\
TDS $(\mathrm{g} / \mathrm{L})$ & $15.63-33.43$ \\
Conductivity $(\mathrm{mS} / \mathrm{cm})$ & $27.00-57.89$ \\
Salinity $(\mathrm{ppt})$ & $14.46-33.60$ \\
\hline
\end{tabular}

3. Pathansali, D. (1968). Some observations on the distribution of Chaetognatha West of Penang Island. Publications of the Seto marine biological laboratory Japan 15: 391-397.

4. Chua, T. E., and Chong, B. J. (1973). Plankton distribution in the Straits of Malacca and its adjacent waters. Special Symposium on Marine Science, Dec. 1973, Hong Kong.

5. Shamsudin, L. (1987). Comparison of oxygen and ${ }^{14} \mathrm{C}$-productivity method in measuring primary productivity. Jernal Sains Nuklear 5(1). 23-29.

6. Salleh, A., Wakid, S.A., Bahnan, I. S., Rahman, K.A.A. and Nasrodin, S. (2005). Diversity of phytoplankton at Langkawi Isaland, Malaysia. Malaysian Journal of Science. 24: 43-55.

7. Salleh, A., Wakid, S.A. and Bahnan, I. S., Rahman. (2008). Diversity of phytoplankton collected during the Scientific Expedition to Pulau Perak, Pulau Jarak and the Sembilan Group of Islands (SESMA). Malaysian Journal of Science. 27 (3): 33-45.

8. Chua, T. E. (1980). A preliminary study of the Coastal and Riverine Plankton of the East Coast of Peninsular Malaysia. In: Coastal Resources of East Coast Peninsular Malaysia (Eds: Chua, T. E. \& J K Charles), Universiti Sains Malaysia, Penang. 241-182.

9. Shamsudin, L. (1988). Photosynthetic values, Light intensity and other related parameters of Sarawak water off the South China Sea. In "Ekspedisi Matahari 1987" Ed. By A.K.M. Mohsin et.al. FPSS, UPM.

10. Shamsudin, L. (1990). Diatom Marin di Perairan Malaysia. Dewan Bahasa dan Pustaka. Kuala Lumpur. Malaysia.

11. Salleh, A., Zan Mirani, T. (2006). Phytoplankton of Carey Island. Aura Productions Sdn. Bhd.
12. Kobayasi, H. (1992-1999). Diatom; The Japanese Journal of Diatomology. Vol 13-15. The Japanese Society of Diatomology, Japan.

13. Round, F.E., Crawford, R.M., Mann, D.G. (1990). The Diatom. Biology and Morphology of the Genera. Cambridge University Press.

14. Fukuyo, Y. (1999). Fighting algal blooms. Seafdec Asian Aquaculture Vo. XXI. No. 2 April, 1999. 43 pp.

15. Descy, J. P. \& Mouvet, C. (1984). Impact of the Tihange Nuclear Power on the Periphyton and the Phytoplankton of the Meuse River (Belgium). Hydrobiologia, 119, $119-28$.

16. Pringle, C. M. \& Bowers, J. A. (1984). An in situ Substratum Fertilization Technique: Diatom Colonization on Nutrient-enriched, Sand Subtrata. Canadian Journal of Fisheries and Aquatic Sciences, 41, 1247 - 51.

17. Pan, Y. \& Stevenson, R. J. (1996). Gradient Analysis of Diatom Assemblages in Western Kentucky Wetlands. Journal of Phycology, 32, $222-32$.

18. Hunter, J.C. \& Rex, L.L. (2007). Nutrient Limitation of Benthic Algae in Lake Michigan: The Role of Silica. Journal of Phycology. 43: 228-234pp.

19. Tait, R.V. (1972). Elements of marine ecology. An Introductory Course. 314pp.

20. Round, F.E. (1984). The Ecology of Algae. Cambridge University Press. 653pp.

21. Dawson, E.Y. (1966). Marine Botany. An Introduction. Holt, Rinehart and Winston, Inc. $371 \mathrm{pp}$.

22. Ting, T. M., Wong, J. T. S. (1989). Pyrodium red tide occurrences in Brunei Darussalam. In Biology, Epidemiology and Management of Pyrodium Red Tides (Hallagreaff, G. M., Maclean, J. L., eds). Fisheries Department Bandar Seri Begawan and International Center 
for Living Aquatic Resource Management, Manila, pp. 19-26.

23. Usup, G., Pin, L. C., Ahmad, A., Teen, L. P. (2002). Alexandrium (Dinophyceae) species in Malaysian waters. Harmful Algae 1, 265-275.

24. Patrick, R. \& Reimer, C.W. (1966). The Diatoms of the United States, Vol. 1. Acad. Nat. Sci. Philadelphia, Philadelphia.

25. Palmer, C.M. (1969). A composite rating of algae tolerating organic pollution. J. Phycol. 